\title{
Critique \\ Ensuring quality in qualitative inquiry: Using key concepts as guidelines
}

\author{
Debra Frances Campbell \\ Afonso A. Machado \\ São Paulo State University, Brazil
}

\begin{abstract}
The field of qualitative scientific inquiry employs a fast-growing variety of approaches, whose traditions, procedures, and structures vary, depending on the type of study design and methodology (i.e., phenomenological, ethnographic, grounded theory, case study, action research, etc.). With the interpretive approach, researchers do not utilize the same measures of validity used in positivist approaches to scientific inquiry, since there is "...no one standard or accepted structure as one typically finds in quantitative research" (Creswell, 2007). With the absence of a single standard, how, then, is it possible for qualitative researchers to know whether or not their study was done with rigor, that it has validity, that it is ready to submit to their peers? The research literature is sprinkled with references to quality in qualitative inquiry, which helps to construe a study's validity. Markula (2008) suggests that we validate our study's findings by assuring readers that it was done "in the best possible way." While each research tradition has its own set of criteria for judging quality, we present here general concepts drawn from the literature. We hope this article will provide a framework from which qualitative researchers can judge their work before submitting it to their peers, one which will help ensure that their study was done "in the best possible way."
\end{abstract}

Keywords: qualitative research, qualitative methodology, validity

Resumo- - "Garantindo qualidade na investigação qualitativa: Usando conceitos-chave como diretrizes." O campo da investigação científica qualitativa emprega uma variedade de abordagens em rápido crescimento, cujas tradições, procedimentos e estruturas variam, dependendo do tipo de projeto e metodologia de estudo (i.e., fenomenológica, etnográfica, teoria fundamentada, estudo de caso, pesquisa-ação, etc .). Com a abordagem interpretativa, os pesquisadores não utilizam as mesmas medidas de validade utilizadas nas abordagens positivistas para a investigação científica, uma vez que é “... não algo padrão ou estrutura aceita como tipicamente se encontra em pesquisa quantitativa" (Creswell, 2007). Com a ausência de um padrão único, como, então, é possível para os pesquisadores qualitativos saber se seu estudo foi ou não feito com rigor, que tem validade, que está pronto para ser apresentado aos seus pares? A literatura de pesquisa é cheia de referências sobre qualidade em investigação qualitativa, o que ajuda a interpretar a validade do estudo. Markula (2008) sugere que devemos validar os resultados do nosso estudo assegurando aos leitores que foi feito "da melhor maneira possível." Embora cada tradição de pesquisa tenha seu próprio conjunto de critérios para avaliar a qualidade, apresentaremos aqui os conceitos gerais resgatados da literatura. Esperamos que este artigo proporcione uma base na qual os pesquisadores qualitativos possam julgar o seu trabalho antes de divulgá-lo a seus pares, uma base que possa ajudar a garantir que seu estudo foi feito "da melhor maneira possível."

Palavras-chaves: pesquisa qualitativa, metodologia qualitatriva, validade

Resumen - “Garantizar la calidad en la investigación cualitativa: Utilizando conceptos clave como directrices.” El campo de la investigación científica emplea una variedad de métodos cualitativos en crecimiento rápido, cuyas tradiciones, las estructuras y los procedimientos pueden variar en función del tipo de diseño del estudio y metodología (es decir, fenomenológico etnográfica, teoría, tierra, estudios de casos, la investigación-acción, etc). Con el enfoque interpretativo, los investigadores no utilizan las mismas medidas de validez de los enfoques positivistas utilizados para la investigación científica, ya que es “... no es algo marco estándar o aceptada como normalmente se encuentran en la investigación cuantitativa" (Creswell, 2007). Con la ausencia de una norma única, ¿cómo es posible que los investigadores cualitativos saber si su estudio se hace con rigor, que es válido, que está listo para ser presentado a sus compañeros? La literatura científica está salpicada de referencias a la calidad en la investigación cualitativa, que ayuda a interpretar la validez del estudio. Markula (2008) sugiere que deberíamos validar los resultados de nuestro estudio asegurando lectores que se hizo "de la mejor manera posible." Aunque cada una tradición de investigación tiene su propio conjunto de criterios para evaluar la calidad, presentamos aquí los conceptos generales rescatados literatura. Esperamos que este artículo proporcione una base sobre la que los investigadores cualitativos pueden juzgar su trabajo antes de liberar a sus compañeros, una base que puede ayudar a asegurar que su estudio se llevó a cabo "de la mejor manera posible."

Palabras claves: investigación cualitativa, métodos cualitativos, validez 


\section{Introduction}

For those of us who investigate "multiple truths" and constructed meanings, those whose ontological and epistemological perspectives are expressed through qualitative methods of inquiry, it makes little use to employ positivist definitions of validity (Henderson, 2006). This is true because, as researchers using qualitative methods, each of us operates "... as a reflexive agent in the field-not only studying the action of others but also studying his or her own responses to others' action" (Lindlof \& Taylor, 2002). The interpretive approach, says Gratton (2004), provides a mechanism through which we can understand the complexities of behaviors and relationships. It allows us to examine concepts that "... are 'measured' using words, statements and other non-numerical measures, collecting data from the viewpoint of the participant."

In the current, fast-changing, poly-vocal (Madriz, 2000) fields of subjective, inductive, multi-purposeful qualitative research, it is necessary, now more than ever, that we take special precautions to ensure the quality of our investigative labors (Creswell \& Miller, 2000). Some suggest that the particular challenges faced by researchers in today's increasingly complex social landscapes contribute to a "crisis of representation" (Parry \& Johnson, 2007; Schwandt, 2007).

One way that qualitative researchers validate our research findings is to assure readers that our study "has been done in the best possible way" (P. Markula, personal communication, Sept. 9, 2008).

\section{Key concepts as guidelines}

With the ever-increasing multitude of approaches to qualitative inquiry (Creswell, 2007, p. 36-37), studies vary in traditions, procedures, and structures, depending on the type of study design and approach (i.e., phenomenological, ethnographic, grounded theory, case study, action research, etc.).Therefore, there is "...no one standard or accepted structure as one typically finds in quantitative research" (Creswell, 2007, p. 42). How, then, is it possible for us to judge whether or not our study has been done "in the best possible way"?

While, indeed, no one method exists, the literature is sprinkled with references to quality in quality research (Creswell \& Miller, 2000; Kvale, 1996; Lieblich, TuvalMashiach, \& Zilber, 1998; Lincoln \& Guba, 1995; Rolfe, 2006; Stake, 1995). We have assembled here a number of concepts that are universally common to "good studies," to those with "quality," and that generally help to construe a study's trustworthiness (Lincoln \& Guba, 1985). These concepts by no means represent all of the methods available to qualitative researchers to help us gauge our study's quality, and, hence its validity. However, we can use various concepts from various approaches throughout the literature as guidelines to help us feel confident that our study will better meet the rigorous standards of international journal reviewers and readers.
For example, Sparkes (1998, 2000, 2002) explains how certain criteria can be used to measure the quality of the narrative, or life story. The qualities present in "good" narrative studies, claims Sparkes (2002), should include certain "emerging criteria" (Lincoln, 1995). Sparkes gives us "starting points" from which to base quality narrative inquiries that are paradigmatically interpretive (Sparkes, 2002). Lieblich, Tuval-Mashiach, and Zilber's classic book on narrative research (1998) provides Sparkes with the following criteria, which he uses to ensure quality in his own narrative study (2002): width, coherence, insightfulness, and parsimony (Lieblich et al., 1998).

Using these same criteria, we will perform a brief analysis of another narrative study - that of Anne, an elite swimmer with an eating disorder, titled "Slim bodies, eating disorders and the coach-athlete relationship" (Jones, Glintmeyer, \& McKenzie, 2005). We can use this narrative as an excellent example of a "good" study, one that satisfies Lieblich et al.'s criteria. We hope that the themes in this brief analysis will give the reader an idea of what to look for in his or her own study, and will provide a framework from which to perform a more thorough analysis of his or her own work.

- Width is "The comprehensiveness of evidence," and relates to "the quality of the interview or observations..." and to "the proposed interpretation or analysis" (Sparkes, 2002). Additionally, width includes the extensive citing of quotations as well as "suggestions of alternative explanations" so that the reader can judge and interpret the evidence. In the life story of Anne (Jones et al., 2005), the authors justify their approach by explaining that, in order to tell a broader story, they used only one voice-that of the subject of the study. Through the utilization of this method, they claimed that they expected to capture the multidimensional aspects of "lived experience," and what Sparkes and Smith refer to as an "inside out approach" (2002).

- Coherence is "The way in which the separate parts of the interpretation present a complete and meaningful picture" (Lieblich et al., 1998). While the narrative of Anne, a female athlete, is the sole "spoken" voice via her narrative, the authors attempt to contextualize Anne's experiences by making obvious utilization of "poly-vocality" throughout their analysis (Madriz, 2000; Markula \& Denison, 2006). That is, they wove many voices and numerous theoretical concepts into their analysis of Anne's narrative to illustrate how her experiences reflect, first, her identity as a strong, yet vulnerable athlete, who feels the need to conform to the culture of "slenderness," and, second, "the role of the coach in this process of athlete identity creation and disruption." The study "... is grounded in the need to tell Anne's story of compliance within a culture of discipline and norms" (Jones et al., 2005). Additionally, the story reveals a broader picture of an absence of awareness about power relations within the field of coach training and coaching practices.

- Insightfulness refers to how investigating the life of another person can result in the reader having "greater comprehension and insight regarding the reader's own life" (Lieblich et al., 1998). The authors' reference to the 
disciplined, athletic body also is an attempt to illustrate how Anne's story is generalizeable, applicable to all of us, or, as Sparkes says, “.... whether it speaks to the reader about their own experiences” (Sparkes, 1998).

The study illustrates how Anne's narrative is only one voice in a larger story that involves other athletes, whose fragile identities are contingent upon their often tenuous relationships with their coaches, as well as other "significant others." The authors invoked theorists such as Foucault (1977) in order to locate Anne's experiences within certain contexts that have universal meanings (i.e., the "disciplined" athletic body, under constant self-surveillance).

- Parsimony (Lieblich et al., 1998) is "The ability to provide an analysis based on a small number of concepts, and elegance or aesthetic appeal..." Through the utilization of one narrative, with the "weaving in" of various theoretical perspectives, the study is an examination that reflects the "truths" of many, through the telling of a universal story.

These criteria also help to constitute verisimilitude (Markula \& Denison, 2006; Stanford Encyclopedia of Philosophy, n.d.). Verisimilitude is the quality of appearing to be true or real (Webster, 2013). In her narrative study, Ellis (1995) uses verisimilitude as a final test of generalizability. She asks:

Did my story engender conversational response toward the text as you read? Did the story illustrate particular patterns and connections between events? Did you give the story to others to read because you think it speaks to their situation? ...What text did you, the reader, create of my story? Did this narrative make you think about or shed light on events in your own life? ... Did the words I wrote elicit from you an emotional response to examine? What did you learn about yourself and your relationships through your responses to my text?

In his classic approach to qualitative inquiry, Fairclough (2001) provides a seminal five-stage model for conducting a critical discourse analysis. It is his final step that is perhaps most crucial to ensuring quality, and should be considered in all modes of qualitative inquiry. It is where "the analysis turns reflexively back on itself, asking... how effective it is as critique..." (Fairclough, 2001, p. 125). Here, the researcher must make certain that he or she has adequately addressed all of the component parts of the study, including its limitations. Additionally, did ethical questions emerge, and were they addressed?

While we know that in the continuously changing landscape of qualitative research there is no single method of guaranteeing the quality of our qualitative study (Creswell, 2007), we know, too, that we cannot be too careful in our continuous attempts to achieve this ideal. Sparkes', Jones et al.'s, and Ellis' criteria were applied here to life stories, and Fairclough's model concerns discourse analysis. Yet, these concepts and other "emerging criteria" (Lincoln, 1995) can be applied more generally, as guidelines in inquiries that employ various methods. We can use them for our own "tests of generalizability." They can help us achieve verisimilitude, credibility, trustworthiness. However, three more topics require discussion, as they are crucial to the achievement of quality in our research efforts: the literature review, the "positioning of self," and the inclusion of our paradigmatic stance.

\section{The literature review: the author's use of previous studies to develop an original research question}

Markula observes that it is the literature review that sets up the entire qualitative study. It helps define the researcher's focus, the problem, what methods will be employed, who the participants will be, and what type of analysis will be required (P. Markula, personal communication, Sept. 9, 2008). Additionally, the literature review helps establish a logical thread, the argument that will inform my research question, which should be explicitly stated, and it will help clarify and justify my study's methodological treatment (see "Paradigmatic framework" below).

\section{So what?}

The literature review also will help me determine whether or not my study will meet the universal criterion, "So what?" (Creswell, 2007). That is, is there a valid reason for me to undertake my study; what difference does it make? Once I complete my study, what are the implications of its findings? Does it have value? Does it add to the collective knowledge in my field? Is it an original study?

\section{Positioning the "self" in the study}

It has been long-argued that researchers cannot maintain objectivity because we interact with our study's participants, and that our relationship with our participants will necessarily affect the collection of data and the outcome of the study (i.e., our interpretations) (Lewis, 2009).

The first such "crisis of objectivity" came in 1915, according to Nararuk (2011), when anthropologist Malinowsky's diaries were made public. The researcher had reported one "truth" publicly in his ethnography, but his personal diaries, published later, revealed another side to the story: his own thoughts about the subjects of his study, the people of the Trobiand Islands. The notations in his diary were found to be racist and sexist, not at all congruent with the writings in his ethnography. The result of these incongruities, says Nararuk (2011), is "the erasure of subjectivity when the diary is compared with the monograph."

In another classic study about the inhabitants of Bali and the cockfights they held regularly, anthropologist Geertz (1973) made an observation that is pivotal to the way we think about our roles as researchers, and the notions of objectivity and subjectivity in research. Nazaruk (2011) explains, “... we first see the anthropologists looking at the Balinese, and the Balinese looking back at them; then a change occurs as the Balinese alter their attitudes toward 
the anthropologists, who in turn begin to see the Balinese differently."

A method used for minimizing this occurrence is called reflexivity. This, according to Creswell and Miller (2000), is "...the process whereby researchers report on personal beliefs, values, and biases that may shape their inquiry." Creswell (2007) further explains how openly describing our relationship to the subject, as well as our beliefs, can give validity to the processes of data gathering and interpretation. He claims,

\begin{abstract}
How we write is a reflection of our own interpretation based on the cultural, social, gender, class, and personal politics that we bring to research. All writing is 'positioned' and within a stance. All researchers shape the writing that emerges, and qualitative researchers need to accept this interpretation and be open about it in their writing (p. 179).
\end{abstract}

Increasingly, qualitative researchers consider not only how their presence and the process of research might affect data collection, interpretation, and the subject of the study. In "sensitive studies" (i.e., the interviewing of people with terminal illnesses or serious disabilities), for example, researchers reveal how the process might affect them-the researcher-as well as the participants (Creswell (2007, p. 179). O'Connor (2011) adds, "When analyzing complex social or situational phenomena, we should be completely explicit about the way in which our attributions may have been shaped by the circumstances in which they occur." He argues that we must always "...take care to include context in our discussion."

\section{Paradigmatic framework}

As with the research question and the "positioning of the self" within the context of the study, the paradigmatic stance should be clearly stated early in the study, because our epistemological and ontological perspectives inform our methodology (P. Markula, personal communication, Sept. 16, 2008; Olson, n.d.; Smith, \& Caddick, 2012). Notes Bradley (1993), “... Active discussion of what we know, in light of how we produced that knowledge, can only extend our understanding..." For example, a content analysis is often thought to be a method used in quantitative approaches to inquiry. However, Smith and Sparkes (2005) explain that “...a content analysis is not a singular, unified procedure or technique..." The authors describe how, by “...using certain epistemological and ontological assumptions..., ... a content analysis... ...can be informed by an interpretative paradigm" (Sparkes, 1992), and can be used to “...connect textual content to broader discursive contexts" (Philips \& Hardy, 2002).

Fairclough (2001) further illustrates how our paradigmatic stance informs our methodology. He argues that methodo$\log \mathrm{y}$ refers to more than a simple set of methods; rather it refers to the rationale and the philosophical assumptions that underlie a particular study. This is why scholarly research often includes a section on the methodology of the researchers. This section does more than outline the researchers' methods...; it might explain what the researchers' ontological or epistemological views are.

\section{A critique as a learning tool}

We saw via Anne's narrative (Jones et al., 2005) above, how, by satisfying certain criteria, the authors incorporated "quality" into their study. We know, additionally, that we must perform a thorough literature review, ask a question that satisfies the fundamental query, "So what?", position ourselves within the context of the study, and discuss our paradigmatic stance. Below is a critique of how failure to employ these important concepts can cast doubts about a study's quality, and its validity and conclusions. We hope that it will build on our earlier analysis, and expand the framework from which you can perform a critical analysis of your own study.

In her article, "The embodiment of class, gender and age through leisure: A realist analysis of long distance running" (2004), author Andrea Abbas examines the development of the sport of long-distance running and its relationship to the production of social inequalities related to gender, age, and class. She attempts to establish "connections between the knowledges, practices, organization and values promoted through running (from 1979-1998) and the growing popularity of a particular bodily type and style" (p. 159): the slender, muscular body.

Abbas' (1992) study concludes that the middle-class forms of masculinity intrinsic to popular long-distance running practices contribute to the devaluing and marginalization of women's and older bodies (p. 172). Finally, she suggests that policy development, based on the notion that leisure sporting activities such as running are a means of promoting good health, should also investigate the quality of social values that such activities might coincidentally produce and promote (p. 173).

\section{Author's use of previous studies to develop an original research question}

Abbas' methodological treatment seems confusing (see "Paradigmatic framework" below). The author initially cites Sayer's realist theory as the theoretical framework for her study. She later invokes a litany of other theorists, ranging from realist theorists to postmodernists/poststructuralists, in order to further develop her notion of embodiment ( $\mathrm{p}$. 160). The attempts seem to fail to clarify the author's true epistemological stance, however, because it is not until deep into her paper, in her "methods" section-what she refers to as "Methodologies...," that Abbas finally declares her methodology. Yet, curiously, she does so tentatively, almost 
incidentally, revealing at last that she employs what can loosely be defined as a "critical discourse analysis" (and hence, a critical theory stance) to examine the sample texts she has chosen. It is not until this point in her study as well that she clearly indicates what the subjects of her analysis are; until now she has made only vague references to the objects/subjects of her inquiry. For example, she claims that her study is "... based upon part of a study which involved analyzing a running magazine..." (p. 159).

As earlier discussed, it is the literature review that sets up the entire qualitative study. It helps define the researcher's focus, the problem, what methods will be employed, who the participants will be, and what type of analysis will be required. Here, it is difficult to follow the logical thread, the argument that informs the study's research question. In fact, the research question is never explicitly stated.

\section{Paradigmatic framework}

Pinpointing the author's epistemological persuasion is not easy. She gives us clues in the article's title and introduction by referencing "a realist approach..., class, age, and gender." In her literature review, as she draws upon Sayer's (1992) "theoretical work," she hints at what the theoretical underpinnings of her study are not. She claims that his "realist philosophy and methodology can inform analyses that avoid the positivism [our italics] of the natural sciences and the interpretive reductionism of some social science perspectives" (p. 160). She informs us that Sayer's “...materialist and dialectic view of change can facilitate studies that incorporate both cultural and structural analysis" (p. 160). She then beckons phenomenologists/ embodiment theorists Csordas and Merleau-Ponty. She continues to reference another embodiment theorist (but with a variation) (Crouch), as well as additional variations of embodiment through "actor-network theorists... (Law...)," and "feminist writers... (Haraway...)" (p. 160). She concludes that numerous social artifacts, including magazines, constitute "the embodiment of running" (p. 161). Abbas continues to build on the works of Borudieu, Butler, and Fournier, as well as on realist theory, to support her use of Sayer's concepts, causal powers and causal liabilities (p. 161 ) in her analysis. "Analyzing running cultures," she claims, "involves identifying causal powers and causal liabilities that are those practices, ideas, objects and organization that are necessary to it" (p. 161).

The author attempts to connect Sayer's theoretical approach to some of the findings in her analysis of "the magazine based literature and pictorial representations analysed as part of this study..." (p. 162). Yet, up to this point in the study, the author has not yet clearly referenced what her methods for analyzing these texts might be or even what constitutes them. At last, Abbas begins to define her methods under the subhead, "Methodology: conceptualizing the embodiment of running" (p. 163). This structuring of her analysis seems to make the study appear epistemologically ambiguous. Is her study based on a realist paradigm, critical theory, a critical realist paradigm, what? What is her methodology? Abbas simply does not make herself clear in this regard, providing justification and, hence, validation for her study.

\section{Method}

If methodology refers to a "rationale that supports a method's validity" (Fairclough, 2001), then Abbas confuses the term method with methodology. The author claims to use an embodied approach to examine texts from a popular running magazine. In her "Methodology..." section, Abbas describes her methods, her use of textual samples and interviews. She examined the "front covers and letter pages of the magazine for complete years, at five yearly intervals, beginning with the first issue in April 1979 and up until March 1995 " (p. 163). She claims that this selection would allow her to study a representative sample, without having to examine each and every year of publication.

Finally, not mentioned in the abstract, introduction, or literature review, but hidden deep in the "methods" section of her study, Abbas reveals her methodological approach. She writes, almost incidentally, that "The mode of analysis was, broadly speaking, a discourse analysis" (p. 163). Critical Discourse Analysis: The paradigmatic framework of the study, clearly stated, finally, is critical theory. Fairclough (1992) explains, that Critical Discourse Analysis (CDA) is both a "theory and a method..." He claims,

CDA is in my view as much theory as method-or rather, a theoretical perspective on language...... as one element or 'moment' of the material social process..., which gives rise to ways of analyzing language or semiosis within broader analyses of the social process. Moreover, it is a theory or method which is in a dialogical relationship with other social theories and methods... (Fairclough, 2001, p. 121).

However, Abbas seems to fail to make this distinction, and, instead, dismisses the theoretical value of CDA completely, focusing only loosely on its utility as a method to examine her texts.

Additionally, with what appears to be with little justification or theoretical support, Abbas conducted ten "unstructured" interviews of runners-but not readers of the magazine - in an apparent attempt to triangulate/validate the findings in her textual analysis. Using a snowball technique to find participants, the interviews, she claims, would help her "see if the messages I identified within the elements of the magazine were also present in runner's [sic] talk" (p. 163). She offered no description of where the runners originated. The taped interviews of the 18- to 50-year-old runners were analyzed "in a similar way to the magazine data," which implies that she performed a critical textual analysis of their transcripts. The only specific evidence of an interview question is one based on a style that researchers should avoid, those to which respondents can only answer 
"yes" or "no" (Patton, 2002): "Do you see running as less aggressive?" (Interviewer) (p. 166). Interestingly, the author mentions nothing of ethics committees, consent forms, or guidebooks in relation to the interviewees. While unnecessary for her textual analysis, the absence of consideration for her human subjects relative to potential ethical issues could cast a shadow of doubt on the validity of her study and on her credibility as a researcher (Kvale, 1996).

\section{How results have been interpreted into a discussion/conclusion}

As stated earlier, a qualitative research study should clearly state its philosophical framework and paradigmatic stance. In the absence of these definitions, clearly stated, Abbas did not articulate or justify the purpose of her study. Did her interpretations of her data, therefore, make sense?

While generally appearing to dismiss Fairclough's rationale for conducting a critical discourse analysis, with one important exception Abbas seems to have closely followed his analytical framework (Fairclough, 1999, p. 125). She:

\footnotetext{
1) problematizes the issue;

2) asks "what is there about social structures that makes this a problem which is resistant to easy resolution," utilizing the concept of "intersections and interactions," and the two aspects of interactional analysis: interdiscursive and semiotic analyses;

3) rationalizes how the social order "needs" the problem;

4) shows how "not fully realized possibilities for change" might exist
}

However, it is in the fifth and final stage of the analysis where the study seems to most fall short. Step 5 is where "the analysis turns reflexively back on itself, asking... how effective it is as critique..." (Fairclough, 1999, p. 125). It is here where the author's adherence to Fairclough's method/ ology fails. The study, it seems, has not adequately turned "reflexively back on itself." The author does not address the limitations of the study except in one instance, although she briefly introduces the idea of theoretical limitations when discussing the particular approach of relating "running culture to social class, age, and gender praxis... embodied practice..." and "...causal powers and causal liabilities..." (p. 162). The sole reference is made in relation to the sample of runners who were interviewed: The ten unstructured interviews, which "did not allow for a representative sample from which it would be possible to make generalizations about 'all runners'..." (p. 163).

More importantly, however, there remains the absence of a clear statement of her research question, her methodology (which reflects the author's ambiguous epistemological stance), as well as the possible emergence of ethical questions. Therefore, the most serious consequence of this failure "to turn reflexively back," it seems, is that doubts about the study's quality, and hence its validity and conclusions, seem imminent.

\section{Summary}

Each of the growing number of approaches used in qualitative inquiry has traditions, procedures, and structures that are specific to the approach, including methods for data collection and analyses. Creswell (2007) describes how the written report, for five common qualitative methods, "takes shape from all the processes before it" (p. 77). He writes,

\begin{abstract}
A narrative about an individual's life forms narrative research. A description of the essence of the experience of the phenomenon becomes a phenomenology A theory, often portrayed in a visual model, emerges in grounded theory and a holistic view of how a culture sharing group works results in an ethnography. An in-depth study of a bounded system of a case (or several cases) becomes a case study (p. 77).
\end{abstract}

With such a diversity of approaches, no single method can guarantee that our study will achieve "trustworthiness" (Lincoln \& Guba, 1985), that it will be done "in the best possible way" (P. Markula, personal communication, Sept. 9, 2008). However, the literature suggests that "good" studies possess certain characteristics. This article is not intended to be comprehensive in scope, but, rather, to provide a brief overview of concepts that are important to qualitative inquiry, those that can serve as guidelines to help ensure quality in our study. It is, by no means, the only way to achieve quality; it is one way, in a seemingly endless sea of possibilities.

We saw via Anne's narrative (Jones et al., 2005) above, how, by satisfying certain criteria, the authors incorporated "quality" into their study. We can use these criteria, width, coherence, insightfulness, and parsimony (Lieblich et al., 1998), to analyze our own study and to feel confident that we have done our "best." We must remember, as Lincoln (1995) reminds us, that the criteria for judging "quality" in qualitative studies are fluid, always changing and "emerging." Therefore, as researchers, we must stay constantly aware of such emerging criteria in our chosen areas, whatever our chosen methods.

Additionally, we must do a thorough literature review, ask a question that satisfies the fundamental query, "So what?", and undertake original research that adds to our collective knowledge. We must position ourselves within the context of the study, and we must explicitly state our paradigmatic stance and theoretical foundation(s) to the reader (even in the case of grounded theory, where the theory is expected to emerge through the data analysis) (Glaser \& Strauss, 1967).

Finally, when we "look reflexively back" (Fairclough, 2001), we must see that we conducted our study with care and purpose and that we interpreted our data correctly 
(Creswell \& Miller, 2000; O’ Connor, 2011). As we saw in our critique of the study on running, the absence of such considerations can have a serious impact on the collection of our data, on our interpretation and findings, and even on our credibility as researchers.

Once we are certain our study satisfies these criteriathat it was "done in the best possible way," that it is "trustworthy," only then are we ready to present our findings to our peers.

\section{References}

Abbas, A. (2004). The embodiment of class, gender and age through leisure: A realist analysis of long distance running. Leisure Studies, 23, 159-175.

Bradley, J. (1993). Methodological issues and practices in qualitative research. Library quarterly 63, 431-449.

Creswell, J.W. \& Miller, D.L. (2000). Determining Validity in Qualitative Inquiry. Theory into Practice, 19(3), 124-130.

Creswell, J.W. (2007). Qualitative Inquiry \& Research Design. 2nd edition. Thousand Oaks, CA: Sage.

Ellis, C. (1995). Final negotiations: A story of love, loss and chronic illness. Philadelphia: Temple University Press.

Fairclough, N. (2001). Critical discourse analysis as a method in social scientific research. In R. Wodak \& M. Meyer (2001). Methods of critical discourse analysis (pp. 121-137). London: Sage.

Foucault, M. (1977). Discipline and punish: The birth of the prison. Cambridge: Polity Press.

Geertz, C. (1973). Interpretation of Culture. New York: Basic Books.

Glaser, B.G. \& Strauss, A. L. (1967). The discovery of grounded theory: strategies for qualitative research. Chicago: Aldine.

Gratton, C. \& Jones, I. (2004). Research methods for sport studies. London: Routledge.

Henderson, K. A. (2006). Dimensions of choice: Qualitative approaches to parks, recreation, tourism, sport and leisure research. State College, PA: Venture.

Jones, R.L., Glintmeyer, N. \& McKenzie, A. (2005). Slim bodies, eating disorders and the coach-athlete relationship. International Review for the Sociology of Sports, 40, 377-391.

Kvale, S. (1996). InterViews: An introduction to qualitative research interviewing. In S. Kvale (Ed.), Ethical Issues in Interview Inquiries (pp. 109-123). London: Sage.

Lewis, J.L. (2009). Redefining Qualitative Methods: Believability in the Fifth Moment. International Journal of Qualitative Methods, 8(2).

Lieblich, A., Tuval-Mashiach, R., \& Zilber, T. (1998). Narrative research: Reading analysis and interpretation. Thousand Oaks, CA: Sage Publications.

Lincoln, Y. (1995). Emerging criteria for quality in qualitative and interpretive research. Qualitative Inquiry, 1, 275-289.

Lincoln, Y. S, \& Guba, E. G. (1985). Naturalistic inquiry. Beverly Hills, CA: Sage Publications.

Lindlof, T. \& Taylor, B. (2002). Qualitative Communication Research Methods (Second edition). Thousand Oaks: Sage.

Madriz, E (2000). Focus groups in feminist research. In N.K. Denzin \& Y.S Lincoln (Eds.). Handbook of Qualitative Research (2nd edition). London: Sage.

Markula, P. \& Denison, J. (2006). Sport and the personal narrative. In D.L. Andrews, D.S. Masonand M.L.Silk (Eds.), Qualitative methods in sport studies (pp. 165-184). New York: Berg.
Nazaruk, M. (2011). Reflexivity in anthropological discourse analysis. Anthropological Notebooks, 17(1), 73-83.

O'Connor, S.J. (2011). Context is everything: the role of autoethnography, reflexivity and self-critique in establishing the credibility of qualitative research findings. European Journal of Cancer Care, 20, 421-423.

Olson, H. (No date). Quantitative "versus" qualitative research: the wrong question. Available online at: http://www.serprofes soruniversitario.pro.br/m\%C3\%B3dulos/metodologia-dapesquisa/quantitative-versus-qualitative-research-wrongquestion

Parry, D.C. \& Johnson, C. N. (2007). Contextualizing leisure research to encompass complexity in lived leisure experience: The need for creative analytic practice. Leisure Sciences, 29, 119-130.

Patton, M. Q. (2002). Qualitative evaluation and research methods (3rd ed). NewBury Park, CA: Sage.

Phillips, N. \& Hardy, C. (2002). Discourse Analysis: Investigating Processes of Social Construction. Thousand Oaks: Sage.

Rolfe, G. (2006). Validity, trustworthiness and rigour: quality and the idea of qualitative research. Journal of Advanced Nursing, 53(3), 304-10.

Sayer, A. (1992). Method in Social Science: A Realist Approach (2nd ed.). New York: Routledge.

Schwandt, T.A. (2007). The Sage Dictionary of Qualitative Inquiry (3rd ed.). Thousand Oaks: Sage.

Smith, B. \& Caddick, N. (2012). Qualitative methods in sport: a concise overview for guiding social scientific sport research. Asia Pacific Journal of Sport and Social Science, 1(1), 60-73.

Sparkes, A. C. (2002). Telling tales in sport and physical activity: A qualitative journey. Champaign, IL: Human Kinetics.

Sparkes, A.C. \& Smith, B. (2002). Sport, spinal cord injury, embodied masculinities and the dilemmas of narrative identity. Men and Masculinities, 4, 258-285.

Sparkes, A.C. (1998). Narratives of self as an occasion of conspiracy. Sociology of Sport Online 1. Available at: http:// physed.otago.ac.nz/sosol/v1i1/v1i1a3.htm.

Sparkes, A.C. (2000). Illness, premature career-termination, and the loss of self: A biographical study of an elite athlete. In R.L. Jones and K.M. Armour (Eds.), Sociology of Sport: Theory and Practice (pp. 13-32). London: Addison Wesley Longman.

Stake, R.E. (1995). The Art of Case Study Research. Thousand Oaks, CA: Sage Publications.

Stanford Encyclopedia of Philosophy. (n.d.). Truthlikeness. Available at http://plato.stanford.edu/entries/truthlikeness/

Webster's Online Dictionary (2013). Available at: http:// www.websters-online-dictionary.org/definitions/Verisimilitude

\section{Additional readings}

Berg, B. (2001). Qualitative research methods for the social sciences (4th Edition). Boston: Allen \& Bacon.

Blommaert, J. (2005). Discourse: A critical introduction. In J. Blommaert (Ed.), Critical Discourse Analysis (pp. 21-38). Cambridge, UK: Cambridge University Press.

Chouliaraki, L. \& Fairclough, N. (1999). Discourse in Late Modernity: Rethinking critical discourse analysis. Edinburgh, UK: Edinburgh University Press.

Creswell, J.W. \& Miller, D.L. (2000). Determining Validity in Qualitative Inquiry. Theory into Practice, 19(3), Summer 2000, 124-130.

Creswell, J.W. \& Plano Clark, V.L. (2007). Designing and Conducting Mixed Methods Research. Thousand Oaks, CA: 
Sage.

Fontana, A. \& Frey, J. H. (2000). The interview: From structured questions to negotiated text. In N. K. Denzin, and Y. S. Lincoln (Eds.), Handbook of qualitative research (pp. 645-672). Thousand Oaks, CA: Sage.

Hammersley, M. \& Atkinson, P. (1983). Ethnography: Principles in practice. London: Tavistock.

Hays, D.G. \& Wood, C. (2011). Infusing Qualitative Traditions in Counseling Research Designs. Journal of Counseling \& Development, 89(3), 288.

Kvale, S. (1996). InterViews: An introduction to qualitative research interviewing. In S. Kvale (Ed.), The Interview Situation (pp. 124- 143). London: Sage.

Markula, P. (2003). The technologies of the self: Feminism, Foucault and sport. Sociology of Sport Journal, 20, 87-107.

Markula-Denison, P. \& Pringle, R. (2006). Foucault, Sport and Exercise: Power, Knowledge and Transforming the Self. New York: Routledge.

Markula, P. \& Silk, M. (2011). Qualitative Research for Physical Culture. New York: Palgrave Macmillan.

Richardson, L. (2000). Writing: a method of inquiry. In N. Denzin \& Y. Lincoln (Eds.), Handbook of qualitative research (2nd ed., pp. 923-948). London: Sage.

Smith, B. \& Sparkes, A.C. (2005). Analyzing talk in qualitative inquiry: Exploring possibilities, problems, and tensions. Quest, 57, 213-242.

Stake, R.E. (2005). Qualitative case studies. In Denzin, N.K. \& Lincoln, Y.S. (Eds.), The Sage Handbook of Qualitative Research (pp. 443-447). Thousand Oaks: Sage.

Yin, R. K. (1994). Case study research: Design and methods. (2nd ed.). Newbury Park, CA: Sage Publications.

\section{Authors' note}

Debra Frances Campbell is a doctoral student in "Human Development and Technologies," São Paulo State University at Rio Claro, State of São Paulo, Brazil.

Afonso Antonio Machado is Debra Frances Campbell's PhD advisor, and is affiliated with São Paulo State University at Rio Claro, State of São Paulo, Brazil.

\section{Correspondence}

Debra Frances Campbell

São Paulo State University at Rio Claro,

Av 24-A, 1515, Bela Vista

Rio Claro SP, 13506-900 Brazil

Phone: +55 3526-4333

E-mail: campbell@rc.unesp.br

\section{Acknowledgements}

The author acknowledges Cnpq for a PhD scholarship. The authors would like to thank the anonymous reviewers for their comments. Declaration of Conflicting Interests: The authors declared no conflicts of interest exist with respect to the research, authorship, and/or publication of this article. 